\title{
InTEgration AND EnCOUNTER IN HUMANitarian Tutelage
}

\author{
Leonardo SCHIосCHET, Vienna
}

\section{Content}

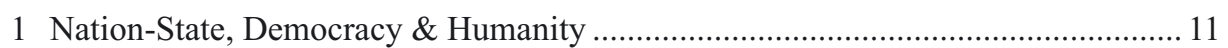

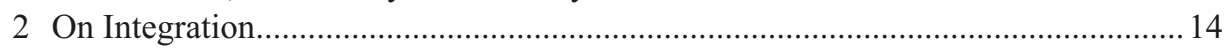

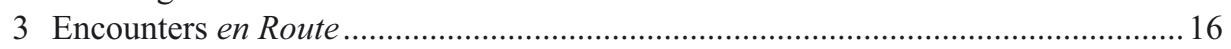

4 Displacement and Violence: from Political Context to Everyday Life .................... 18

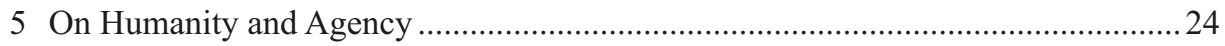

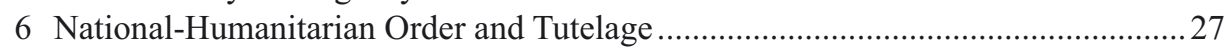

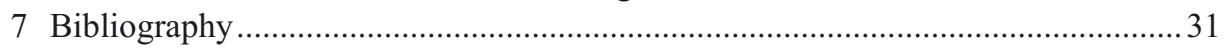

The impressive analytical depth of this volume stems from a joint effort involving scholars associated to the Refugee Research and Outreach Network (ROR-n) to compile and interpret data generated by a pilot study funded by the Austrian Academy of Sciences (ÖAW) and led by the Institute for Urban and Regional Research (ISR) and the Institute for Social Anthropology (ISA) - two of ROR-n's many associated research institutes.

Most of the refugees in the world come from the Middle East and Central Eurasia, and most forced migrants in Europe also come from this region (Sсніосснет, 2016; 2017a). The so-called Summer of Refuge, when unprecedented numbers of forced migrants applied for asylum in Europe in summer 2015, made this fact apparent from Portugal to the Balkan Peninsula. This edited volume contributes with in-depth qualitative data on forced migration from the Middle East and Central Eurasia to Europe, by means of discussing how Syrian, Iraqi and Afghan refugees reached Austria and relate to this regional and urban context. The research presented here focuses on the unique moment of the first experiences of these refugees in Austria, which is essential to understanding the development of the interaction between refugee and host over time. 
This "presentist" (George STOCKING $\mathrm{J}_{\mathrm{R}}$, 1968) outlook from the point of view of the victims of displacement is also in tune with established and contemporary scholarship on memory and agency (Halbwachs, 1992; SAYigh 1998; RadSTONE, 2000; SA'ADI \& Abu-Lughod, 2007; Tedlock, 2009; Passerini, 2014). Thus, the importance of this timely contribution can hardly be overstated.

Europe is in dire need of a reexamination of attitudes towards forced migration, and Austria is no exception. One term in particular always comes to mind when such attitudes are considered, either relating to the host society or to refugees and asylum seekers: integration. But what is integration? What are its conditions of possibility? How is it mobilised as discourse and practice? And, what does it leave out of the picture, if anything?

These are some of the most pressing questions posed by the arrival of large numbers of refugees to Europe during the summer of 2015, dubbed in Europe "the Summer of Migration". This volume is a report on a pilot study conducted by researchers of the Refugee Outreach \& Research Network (ROR-n), investigating the attitudes of Syrian, Iraqi, and Afghan asylum seekers and refugees in Austria. Yet, it is also a timely effort to address the above-mentioned questions through first-hand data and state of the art theoretical-methodological approaches. Each chapter addresses integration, or rather, what I prefer to call "the encounter" between refugees and their hosts, by exploring different aspects, nuances, and diverse transdisciplinary competences.

I use the term "encounter" to challenge assumptions entailed by the term integration in a similar way that Lieba FAIER and Lisa Rofel engage with the term:

"These ethnographies explore how culture-making occurs through unequal relationships involving two or more groups of people and things that appear to exist in culturally distinct worlds. The term encounter refers to everyday engagements across difference. Ethnographies of encounter focus on the cross-cultural and relational dynamics of these processes" (2014: 363).

Yet, my discussion emphasises instead the meeting between migrants, forced or otherwise, and their hosts (Schiocchet, 2017b). My point is not to discredit the importance of the concept of integration in general, only to suggest that encounter is more suitable as an academic tool to investigate how different worldviews influence each other upon contact, which in turn does not take for granted the normative imperative of fitting one to the other standards. While integration remains an important policy tool, academics should first investigate the encounter at large and only then seek answers to integrating policies. This more holistic standpoint, in turn, gears the discussion on the topic toward what Noel Salazar and Alan Smart called (im)mobility (SALAZAR \& SMART, 2011). However, while SALAZAR and SMART rightfully stress the importance of physical immobility when considering refugees, my focus is on the experience on immobility. As I develop elsewhere, refugees - obliged to cross borders rather than stay at their places of origin, living in overcrowded shelters, and serving as easy prey for war machines 
surrounding them - often do not feel mobile but immobile even when jumping countryto-country and continent-to-continent (SCHIOCCHET, 2017a).

Thus, in this introductory chapter, I will familiarise the reader with the chapters and with how each has engaged the current literature on refugees and migrants to, in one way or another, deal with integration. This in turn will highlight the theoreticalmethodological foundations of the contributions in relation to the contemporary challenges of migration and forced migration studies. In this sense, I argue that this edited volume grappled with the interface between integration and what I call encounter, offering pioneering insight into the intersection between the academic study of forced migration and policy. Finally, I contend that the refugee voices heard in this book at large suggest that the encounter between refugees and Austria and Austrians is best understood through the lens of tutelage. The concept of tutelage, in turn, has been only rarely applied to the anthropological understanding of refugees, and more often to the study of indigenous minorities (PAIne, 1980; DyCK, 1991; LiMA, 1995, 2008; PALMiÉ \& STEWART, 2016) or international legal regimes over given territories and their populations (Goertz \& Diehl, 1992; Alston \& Macdonald, 2008; Berman, 2011). The sections below will present and critically engage the chapters through key topics highlighted in this edited volume, before presenting my own general conclusion about the encounter and tutelage.

\section{Nation-State, Democracy \& Humanity}

While most contributors to this volume are anthropologists, political scientist Monika Mokre is an exception. MoKre's interest in broad questions regarding the Austrian nation-state competencies as informed by democratic principles and liberal notions of humanity, is an ideal point from which to depart in exploring this volume, before focusing more directly on forced migrants themselves and their attitudes toward Austria. To her, Austria is today a "split society", productive of the Welcome Culture and concomitantly engaged in border closures. Inasmuch as this apparent inconsistency seems new today, it is only the latest iteration in a series that seem to follow a global pattern, which the specialised literature she mobilises makes evident. As can be deduced from her account, sustaining this inconsistency are democratic values coupled with fears of identity loss and the wellbeing of the rule of law. Integration, thus, is at once valued and discredited.

Questioning how refugees can integrate and be integrated, supported by Charles TAYLOR (1992), she argues that liberal egalitarian principles are based on an understanding of human dignity that is in turn dependent on autonomy, understood as the ability of each person to determine for themselves a view of their preferred life. Egalitarianism, or equality, along with a respect for human dignity, are notoriously difficult to uphold regarding vulnerable subjects, particularly when the state overstretches its capabilities. 
Thus, Mokre argues that it is against this background that refugee policies should be considered. She reminds us that the rule of law as presupposition of democracy must apply also to non-citizens in a given territory, as evidenced in Article Six of the Universal Declaration of Human Rights: "Everyone has the right to recognition everywhere as a person before the law” (1948). This reflects global North's liberal-inspired moral requirement of respecting human dignity.

Yet, Mokre claims that, perhaps despite these liberal principles, integration depends not only on individual autonomy, but also on collective cohesion, which in turn has external and internal dimensions. In the democratic global North, the external dimension is usually citizenship, which works as an apparatus of inclusion just as much as of exclusion. The internal dimension, in turn, is based on trust and loyalty to the state and fellow citizens, although not necessarily equating to political decision making. In this way, refugees are also non-citizens, subject to laws that they are excluded from shaping. This observation is in line with both classic works such as Liisa MALKKI (1995) and Michel AgIER (2008), and cutting-edge works such as those of Ilana FeldMAN \& Miriam Ticktin (2010), Didier Fassin (2012), and Michel Agier (2012), which emphasise that in the national/humanitarian order of the world, citizenship is a precondition of full human rights. According to MoKRE's argument, integration is often taken as condition of possibility for refugees to become citizens of a given host state, being thus the external (inclusionary/exclusionary) dimension of collective cohesion that which defines their condition. I suggest this means that refugees are subject to a social contract they cannot negotiate, which brings us to the principle of tutelage. According to the Merriam-Webster dictionary, "tutelage" means "an act of action of guarding or protecting (...) the state of being under a guardian or tutor (...) the right of power of a tutor over a pupil (...) dependence (...) a determining influence exerted over an individual by a person, school, or movement" (Webster's Third New International Dictionary, 1986, p. 2470). That is, under tutelage, a subject or population considered not to have the full capacity to make its own decisions and is governed by another party that acts as its benefactor. Supported by liberal principles or not, tutelage exists as much in liberal democratic societies as it does in other forms of political organisation. Insofar as refugees do not decide their own fate and do not participate in shaping the policies affecting them, they are by definition under tutelage.

To MoKre, being informed of the rule of law in a nation-state by its competent officials and courts, including rights, legal status, and the consequences of subject's decisions, has an important impact on human dignity, and consequently on the liberal and democratic principles of places such as Austria. This is valid not only for citizens of such nation-states, but also refugees and other non-citizens. It is thus significant that, according to her, $30 \%$ of the interviewees in the research presented in this volume expressed having good knowledge of their legal situation. Yet, more than $25 \%$ expressed having inadequate knowledge of their legal situation in Austria, often being "extremely confused" and "traumatised". While the research also revealed that informal networks of refugees and asylum seekers help to spread legal knowledge in Austria, this is a 
duty of the state, as it is part of the necessary information to enforce the rule of law, but also to foster human dignity and, more to the point, encourage integration. Besides knowledge of legal procedures, access to education (including learning the national language(s)), healthcare and the labour market are also necessary components to the successful integration of refugees. In this sense, the research presented here also reveals that the Austrian policies in this regard were often insufficient.

I would like to suggest that the negative experiences of refugees vis-à-vis their integration must be first be analysed against the background of the generalised confusion and trauma many face already due to the flight and its causes, and not only a host country's inadequate refugee policies. Yet, it is also necessary that the host state takes into consideration these difficulties when devising refugee policies. That is, by the same token, refugees' difficulties in integrating cannot be considered the fault of the refugees', and a successful refugee policy cannot rely on total integration, but must instead take into consideration some measure of failure in this regard, and create or strengthen support mechanisms to cope with this reality. To simply reject this "failed" contingent by deporting them from national territory entails considering refugees in the plenitude of their capacities as subjects. This, in turn, is in direct contradiction with both the principles of tutelage and respect for human dignity.

Meaningfully, the interviewees also see the Austrian state in a more positive light than the institutions, such as national and international NGOs, with which they interact routinely. They also trust the rule of law, emphasised by representations of their country of origin as corrupt. Overall, the vast majority of them have highly positive perception of Austria and the Austrians, which MoKRE suggests could be associated to the days of Welcome Culture prevalent when most first arrived that later turned into the "walls' up policy" (MoKre 2016). MoKrE's chapter, as others in this volume, suggests that most negative assessments of Austria, in turn, were related to feelings of disenfranchisement, rather than having been already in place prior to the refugees' arrival in Austria. Disenfranchisement, of course, is the flip coin of integration. This therefore suggests that to avoid such feelings and the actions they may provoke, integration may be more efficient than deportation, for while deportation may drive away individuals only after they are identified as troublesome or potentially so, integration should prevent subjects of becoming troublesome in first place. Furthermore, MoKRE's chapter also suggests that when integration policies are extreme as to be perceived as assimilation instead, refugees tend to resent and resist such policies. As a refugee she quotes stated: "It's about respect for, for yourself and for people itself" - which incidentally is in line with the principle of respect for dignity that constitutes an underpinning of democracy. This supports MOKRE's proposition that growing fears of outsiders and xenophobia in Austria pose a major threat to refugees, and I would suggest, to democracy in Austria at large.

Likewise, Mokre states that based on international conventions, EU law, national legislation and action plans, but also on the principles of liberal democracy, it is necessary to improve structures and procedures relating to asylum and refugee law in 
Austria and Europe in general. In particular, knowledge about legal statuses, procedures and rights should be communicated to the refugees, regardless of their mother language. Since migration, forced or otherwise, is a strong element shaping contemporary European societies and will likely remain so for decades to come, social cohesion can only be enhanced by providing newcomers the conditions of possibility for autonomous participation.

\section{On Integration}

Josef KOHLBACHER's chapter in this volume stresses the importance of timing. The data collection itself meant to produce timely information about one of the most controversial themes of our times, especially in Europe. However, KoHLBACHER also brings to the fore a less evident need to capture the displaced subjects' own first impressions of their flight, and of the contact with Austria, Austrians, and those involved in the process of flight and settlement in a foreign country, being police officers, NGO representatives, case workers, language tutors and others. Looking at this first phase of displacement is as important as looking at protracted situations, and comparing both can shed light on the diachronic development of the displacement process.

"Integration" and "cultural" and "interethnic contact" are privileged theoreticalmethodological sites for such a study. To KOHLBACHER, integration is a multidimensional process in which social actors - refugees and others - have flexible roles. Moreover, integration plays out in two main domains. The first, "structural integration", is characterised by relations between refugees and the national administrative apparatus of the host state. The second, "social integration", is characterised in turn by informal ties between refugees and the host society. Structural integration affects access to labour and housing markets, social welfare, and regulates the formal status of the refugees in a given country. Social integration - also often called "acculturation" - in turn, is the process through which refugees or migrants develop identities and practices relative to their new context.

KOHLBACHER rightfully avoids the many known shortcomings of the language of "acculturation" and focuses on the more dynamic and less normative concept of "social integration" instead. Social integration is thus, according to him, the process of inclusion of migrants (whether forced or not) within the system of relations and statuses of the receiving society, which entails developing feelings of belonging and identification. Throughout his chapter, he also rightfully acknowledges that "integration" must not be confused with "assimilation", and that "integration" does not require the effacement of social, cultural, religious, or ethnic beliefs and practices, as frequently entailed by the language of "assimilation" and "acculturation". While it is possible to have any combination of high and low degree of structural and social integration, the social 
dimension is essential to a successful integration. Finally, KOHLBACHER is also aware that the notion of integration itself often carries the same assumptions of those of "acculturation" and "assimilation", as it may be understood as impositions on migrants to fit in, as opposed to an indicator of the wellbeing of the relationship between migrants and the host society. Conversely, his less normative and more dynamic definition, which he critically engages through qualitative content analysis, network theory, and Bourdieu's concept of "social capital", remains a useful tool to both scholars and policy makers in understanding the processes of coping with displacement and relocation, and their psychosocial effects. KOHLBACHER focuses his contribution on the analysis of modes of social interaction of refugees in Austria and the structure of these relationships, and on developing a working concept of integration. However, it is also important to note the polyvocality associated with concept of integration, as it has been used by scholars, state agents, international organisations, the media, and others, in radically different ways. An equally important and complementary methodological strategy for social anthropologists must be to understand how one particular definition or another affects the lives of refugees, prior to defining a sociological category of its own right. Such specific definitions can be, for example, that of the host state that defines policies, the working definition of the UN, imprinting ideological value to the notion, or that relating to the refugees' own expectations.

KOHLBACHER convincingly argues that social integration is a process of change, involving both "weak" and "strong ties" among the wide range of social actors mentioned above, and that the initial contact is of foremost importance in terms of "attitudeshaping" of both the displaced and the host, through both institutional and interpersonal interaction. This perspective is supported by an established literature on interpersonal interaction and interethnic contact in the social sciences and humanities (GoFFMAN 1963, 1967; Oliveira 1964; Barth 1969; Gadamer 2004). "Weak ties" reflect thin, feeble connections, while "strong ties" are durable and deep in character. KoHLBACHER states that the data analysed points to the fact that weak ties among forced migrants and other social actors in Austria were proven to play a considerable role in leading to strong ties, hence having a positive effect on integrating the foreigners into the host country. Informal social contact between the forced migrants and the established community were of vital importance in this process, and are particularly relevant for the refugees' integration, and reflected in the establishment of sustainable networks, attitude-shaping about refugees and by refugees about Austria, and other processes of social and structural integration. Thus, KOHLBACHER proposes using the concept of "bridging" alongside of that of "bonding" to understand how situated social actors overcome differences and move towards integration. Correspondently, resources fostering integration are conveniently identified as "bridging capital".

As with all other chapters in this collection, KOHLBACHER's approach is not blind to diversity, but is sensitive to the varied experiences of contact revealed by the study. Experiences of contact, from the point of view of the refugees, depend on class, gender, 
level of education, language proficiency, country of origin, ethnicity, and other variables. In general however, only a minority of refugees reported experiences of being rejected. KOHLBACHER correctly suggests that this may be the outcome of the comparatively negative mood in the refugees' countries of origin and of its contrast to the "Welcome Culture", that is, the general empathetic mood in Austria towards the plight and the predicament of the refugees during the so-called "Summer of Migration" arguably dominating until the end of 2015. Readers must have in mind that the general conflictual contexts in the countries of origin did not efface completely solidarity networks there, and that the positive mood in Europe was short-lived. This assessment reflects thus the moment of data collection and the European context, but nonetheless stands as an important reminder of a distinctive moment in Austrian and global contemporary history ${ }^{1}$. Besides, I suggest that this also reflects refugees' engagement with researchers, which always entails a certain level of speaking what interviewees judge researchers want to hear, and in this particular case possibly strategies to maximise social capital, as I will develop later in this introduction. While some may judge this as a limitation of this particular research, I maintain that all social research entails such structural limitation, and that the research we present here treated it in terms of an actors' positionality, and sought to further address it as qualitative data to understand the structure of the contact itself. That is, social actors and researchers are always positioned, and social research, rather than trying to overcome this positionality, must instead address it as productive of knowledge. As Hans-Georg GADAMER says, as a matter of "fusion of horizons" that goes beyond the naïve classical hermeneutical assumption that interpretation depends on the interpreter fully dislocating their cognition to that of interpreted or to neutral, supposedly ontological, a-historical, a-cultural, ground (GADAMER, 2004). In fact, KOHLBACHER argues that the knowledge produced by this study contributes to the overall knowledge on integration exactly because the bulk of research on the theme so far in Europe has focused on the hosts' perspective, while little attention has actually been paid to that of migrants and even less so refugees.

\section{Encounters en Route}

In Being en Route, in Transit or Protracted, Denise Tan focuses her analysis on arelatively neglected topic in refugee studies. Bringing the concept of "transit migration" (Düvell et al., 2014) from migration into refugee studies, she stresses the importance of understanding the flight not as a linear process, but emphasising instead how routes and plans - and I would add, perspectives - are shaped while en route (WissinK et al., 2013). To achieve this goal, TAN combines an analysis of the ROR-n pilot plan research with her own first-hand material about the situation of Syrian, Afghan and Iraqi refugees in Izmir, Turkey.

\footnotetext{
For more on this, read Monika Mokre's post at ROR-n's blog (MoKre, 09/05/2016).
} 
Already in the 1990s, network-mediated migration scholars challenged the sendingreceiving assumption by stressing the existence of multiple destinations (BRETTEL and Hollifield 2015, p. 159). Yet, the network approach does not account for all experiences of (forced) migration, and in the cases where networks are vital, they still may not account for the whole process. For example, according to TAN (and as seen with MOKRE) several of the interviews analysed describe refugees arriving in Austria without even knowing which country they were in. Furthermore, what about refugees who do not have yet such established networks? How do these networks get established in first place? What about those who lack the resources to access such networks? Furthermore, by focusing only on movement, one effaces that which does not move (or at least does not move all the way). What about those who do not manage to move, such as internally displaced persons (IDPs), or those who plan to arrive at a destination and end up in another? After all, despite the uproar, Syrian, Iraqi and Afghan refugees in Europe are just a fraction of the total number of refugees from these countries, the overwhelming majority remain in the Middle East (Schiocchet 2016; 2017a). Besides, according to TAN, broad comparisons and first-hand ethnographic accounts of people en route are still rare. She approaches these questions by investigating refugees in Turkey in comparison to those in Austria, granted that Europe was the goal destination of at least $35 \%$ of them.

Perhaps the first challenge in operationalising the term "transit migration" is to define who is in transit. There is a thin line separating transit migrants, labour migrants, asylum seekers, and forced migrants, as migrant flows in general are often complex and heterogeneous and more than one label may apply to the same subject. Protracted refuge is emblematic of this complexity and liminality (Снатту, 2010). For example, should Palestinian refugees in Lebanon, some of whom have been living there for over 60 years without citizenship and general human rights, wishing to but prevented from returning to their villages of origin in what today is Israel (Schiocchet, 2014), be considered transit migrants? Even labelling a specific type of migration or migrants as in transit, or en route, entails having another type which is by definition not in transit. The concept may also emphasise mobility over immobility, as routes, rather than subjects' experiences, are the main object of the concept. Another possibility would be to consider all migration as being en route, where routes are symbolic migrant topologies expressing broad worldviews and motivations. Nevertheless, this is not the path explored by TAN in in this volume.

According to her perspective, definitions focusing on intentions obscure the dynamics of the process, as both structural and individual factors shape migration routes. Acknowledging the importance of distinguishing between different empirical social phenomena, TAN proceeds by carefully but loosely defining transit migration, as it is common in the literature (DüVELL et al., 2014). Within the EU, the concept has been usually used in the context of illegal border crossing. Those forced migrants interviewed for the pilot study come from war-torn areas of Syria, Afghanistan and Iraq, arriving in Austria in 2013, 2014 or 2015. Turkey played a key role for a large majority 
of them during the flight to Europe. Furthermore, many Iraqis and Syrians moved to Lebanon or the Gulf before reaching Turkey or directly Austria, and many Afghans lived in Pakistan or Iran prior to reaching Turkey or Austria. One does not need to define a transit period as opposed to one of permanence to define different transit phases within a given trajectory, especially if these phases stem from the migrant's own perspective. In this sense, TAN heuristically divides the flight in three phases, according to the refugees' own experiences. The first is "leaving home", the second is "arrival and stay in Turkey", and the third is traveling to a third destination. She states that among the interviews she analysed and her first-hand interviewees in Turkey, the transit period from the refugees' countries of origin to Turkey or Austria varied from a few days to up to nine months.

Both TAN's perspective and the alternative I suggest have advantages and limitations, and both relativise the usefulness of the concept of integration, as host states and their citizens are not necessarily perennial entities either from the point of view of the refugees, or from an external standpoint to both refugees and host states. The concept of encounter, in turn, is flexible enough to account for the multiplicity of routes, plans and motivations, and the often-transient character of migration, especially within the EU. Furthermore, it can be mobilised together with integration, whenever integration is used not to account for the broad diagnosis of a given situation, but to limitedly express, for example, policy efforts of host nation-states and how refugees and citizens relate to them.

\section{Displacement and Violence: from Political Context to Everyday Life}

People do not flee countries only to save their own lives. Inasmuch as this affirmation seems trivial, forced migration studies have overwhelmingly focused on political persecution and personal life threats as reasons for flight. This is Gabriele RAsulyPALECZEK main argument in this volume's Many Reasons for Leaving Afghanistan: Social Obligations in Times of Protracted Violence. According to her, reasons for flight are often complex and do not boil down to a single factor. As the ROR-n pilot study demonstrated, this is the case at least among Afghans who have recently fled to Austria for personal motives, like escaping from forced marriage or family vendetta, or to honor social obligations, like to give their children a better life. I suggest that forced migration studies is intrinsically tied to juridical definitions of categories such as "refugee" and "asylum seeker" developed to shape policy, and this is among the main reasons for the scholarly focus on persecution.

Conjectures aside, RASULY-PALECZEK's point is well-supported by the pilot study's empirical data and, as she suggests, it is imperative to rethink the way scholars approach the subject. Yet, this must not be seen as weakening refugee policy, as her chapter also 
demonstrates how personal reasons and social obligations intersect structural vulnerability and, in the case of Afghans (as in the case of Palestinians, Iraqi and Syrians), generalized protracted violence. Putting humanitarian expectations aside, this is equivalent to say that, at least from the point of view of vulnerable Afghans, personal reasons and social obligations often motivate flight at least as much as fear of persecution. Or, following the thread of my argument about humanitarian reason, while humanitarianism values are constructed around the ultimate value of human life, asylum seekers not always put their own lives above the lives of others, above social norms, and above personal drives, which in turn should not be an argument to refuse asylum but only to understand flight in greater depth.

Following Larry GoOdSON (2001), RASULY-PALECZEK characterizes Afghanistan as defined by a "Kalashnikov culture", in which many decades of protracted displacement and dispossession, allied to the dissolution traditional of forms of livelihood, eroded the social tissue and overstretched social networks' coping strategies, normalizing violence. Hence, according to RASULY-PALECZEK, reasons for flight generally relate to generalized insecurity and the lack of economic means. Yet, the tipping point is often a personal reason, like a conflict with one's the mother-in-law or to avoid forced marriage.

However, it is important to notice that highlighting the importance of social norms is not the same as to say that subjects are completely determined by these norms, only that these norms are pervasive and shape people's engagement with the world and their forms of expression. That is, to borrow from Lacanian psychoanalysis (LACAN, 1949), while one may express that the ultimate reason for flight was to escape a forced marriage, this must be taken as a token of the imaginary realm of the subject - the subjective or mythic world created by the subject's psyche, or the background story in which the realm of the symbolic unfolds to cope with reality - rather than necessarily as face-value. Fleeing forced marriage, for example, is actually fleeing from a social norm, rather than simply to comply with it. The point is rather that people feel bound to these social norms and have to deal with them, in one way or another, as much in practice as in discourse.

Thus, one especially useful way to develop the implications of RASULY-PALECZEK's well-argued need to reconsider reasons for flight is to contemplate all sorts of motivations as embedded in the idiom of social norms, and not as concurrent sorts of motivations (i.e. personal vs social norms vs fear of persecution). Conversely, social norms themselves are also shaped and influenced by structural violence. So, while persecution in the context of a Kalashnikov culture is structurally influencing people's motivations for flight, these motivations are often expressed in ways that directly relate to one's particular life context, rather than expressed solely or mainly in the idiom of collective violence, which in turn corresponds to humanitarian expectations.

Moreover, while it is generally accepted that violent conflict in the global South remains the main driving force behind forced displacement, it is less acknowledged that its impacts, especially when it comes to protracted refuge, are pervasively felt beyond 
the duration of such conflicts and in the world at large. Andreas HACKL's The Many Faces of Displacement: Pervasive Violence and the Dissolution of a Livable Life in Iraq, Syria and Afghanistan departs from this perspective, familiar to postcolonial (SAID 1985; FAnON 1965, 1986; MBembe 2001; MAMdANi 1996; Wallerstein 2004), subaltern (Guha, 1997; Chakrabarty, 2000; Spivak 1999) and decolonial studies (Mignolo 2000; QUIJANO 2007), to analyse "intersecting push-factors" provoking flight and consequently displacement. He focuses on Iraq, occasionally offering insights from the Syrian and Afghan cases.

To Hackl, as to Rasuly-PaleczeK, motivations for flight cannot be simplified and isolated, and violence - and consequently displacement - cannot be disconnected from poverty and poor institutional development. As I develop elsewhere vis-à-vis the Palestinian and Lebanese cases, just a few years of war is able to undo decades or even centuries of social behaviour and institutional development. It consumes the very fabric of social relations by pervasively instilling suspicion and corroding trust inside and outside a given society. As trust becomes a rare commodity, subjects tend to turn increasingly inward, polarising groups against each other and the outer context (SCHIOCCHET 2014b). Against this background, HACKL concludes that violence and persecution are just part of what pushes people into exile, for they provoke state failure and engender socioeconomic challenges that also act as push-factors. This is not the same as to say that institutional failure is the cause of all problems in a given country, as some of the most radical examples of the failed state/weak state perspective would suggest (CALL, 2008; NAY, 2013); firstly, because international military intervention, war, and the postcolonial context of the world are more than just an institutional problem and secondly, because often no potential factor alone is the origin of violence. Yet, institutional failure, and the many other consequences of international military intervention, war and the postcolonial context of the world do tend to significantly increase violence. HACKL's chapter illustrates that the decision to flee has multiple interrelated motivations, often with consequences for large familial units, rather than just to the fleeing individual. In doing so, it argues that the process of displacement is multi-layered and complex, emphasising that much of the so-called "refugee crisis" takes place not in Europe, but in the Middle East. Yet, it is important to note as I do elsewhere, that while most of the refugee crisis is indeed felt in the global South and in the Middle East in particular, it does exist in Europe mainly as a crisis of identity, representation and policy not brought about the refugees themselves, but made hyper-visible by their presence (SсHіосCHET, 2016).

HACKL reminds us that Iraq is an iconic case of the scenario he describes. Violence there fits conforms to the statistic of $90 \%$ of civil wars starting in countries that have had war in the last 30 years. As the state becomes fragile, it loses its territorial grip and popular support. As a result, Iraq is the state with most internally displaced persons (IDPs) worldwide, rivalling even Syria. Dispossessed, and forced to join local militias, many are pushed to leave their homes and ultimately their country. Amidst the abundance of militias and para-military groups, refugees are pushed by forces emanating often from their very nation, religion, and ethnic group, which must lead experts to think of 
forced migration beyond simple ethnic, national, or religious persecution. As Ussama MAKDISI brilliantly illustrates, even sectarianism is often a consequence of violence, rather than simply its cause (2000). As the Middle East case clearly proves, violence and sectarianism have often reinforced each other (MAKDISSI 2000; JABBAR \& DAWOD 2004). In such a bleak context and as HACKL explains, even in the absence of a directly targeted threat, chronic fear, leads to generalised suspicion and is one of the main causes of flight, and the refugees' very decision to leave is already representative of both the choices they have and those they make. Yet, nation-states and many of their citizens increasingly engage refugees through a security perspective instead (their own security, that is), pressuring the legal status of refugees to be given to an ever-smaller number of asylum seekers.

Moreover, HACKL demonstrates how political and domestic violence are tied to each other. Violent conflict also challenges collective moral and ideological standards, causing violence engendered in the public realm to move into the private realm, disrupting family bonds in the process. The examples he analysed highlight the "articular vulnerability" of women in face of political violence and displacement. Likewise, in Journey to Europe: Memory and the Path to Tomorrow, Noura KAMAL highlights the expediency of a gender perspective about refugees. She analysed a small sample of Syrian interviews from the ROR-n study presented here, half of them with men and the other half with women. She found significant differences in the way men and women remember and represent the conflict and flight, and different gendered dispositions regarding life in exile. While a gender perspective on refugee processes is critical, working on small samples always involves the risk of turning critique into stereotyping. Aware of this danger, KAMAL is reticent to ascribe different behaviours to men and women, but still finds value in exposing the visible differences she found without attributing much normativity to her analysis. Above all, she acknowledges that individual variation may partially account for some of the differences she found, but gender seems to be indeed an imperative variable.

According to KAMAL, simply mentioning and describing how refugees were able to cross borders to reach Austria or any other destination cannot possibly account for the depth of the refugee's experiences. Instead, looking at memory through narratives can shed light on critical concealed aspects of their lives, including how different subjects confront the challenges they face. Yet, engaging with Kleinman \& KLeinman, she understands that, in the hands of the media and the humanitarian apparatus, "trauma stories" can become symbolic capital, or "currency" for "physical resources" and to "achieve the status of refugees" (KLEINMAN \& KLEINMAN 1997, p. 10). This causes double suffering: first when refugees experience the events leading to the trauma, and second when their trauma is transformed into a victimisation narrative that effaces their own subjectivity and decontextualizes their pain. Consistent with KAMAL's argument, it could be argued that women suffer three times, the third relating to "the burden they carry on their shoulders just because they are women". Thus, scholars dealing with trauma should be cautious when reappropriating refugee narratives - women's in particular. 
Seeking to avoid this danger, KAMAL's chapter fits well within the tradition of "narrative ethnography", championed by Lila ABU-Lughod and created as a reaction to what this author saw as excessive "ethnographic typification". This ethnographic tradition prescribed maximal richly detailed particularistic accounts, avoiding comparison (LindHOLM, 1995), which "challenge the capacity of anthropological generalizations to render the lives, theirs or others, adequately" (ABU-LugHod, 2008).

The most striking gendered difference KAMAL found among the interviews was the fact that men's narratives of war and exile tend to portray themselves as engaged social actors as opposed to women, whereas women's narratives tend to portray men, women and often even children as active social actors. However, both men's and women's narratives show that women did play active roles and participate in decisionmaking before and during the war in Syria, as well as during their flight and in exile. She carefully attributes these different narratives to power relations assumed in gender roles in the Arab Middle East, as men are expected to be family providers and act as family leader, even if domestic decisions involve women's input. The rich descriptions KAMAL presents seem to indicate that although both men and women are political subjects, politics itself is defined as a male realm, marginalising the role of women's agency in the public sphere. In practice, this was often reflected in the interviews by men being apparently more eager to please host state representatives and interviewers than the women, who, according to KAMAL, seemed to be less engaged in trying to maximise their gains. All these elements constituting the gender role-set at play in this context point to a gendered grammar, according to which men tend to narrate in the first-person singular, while women tend to narrate in the first-person plural. This grammar can be a powerful tool through which scholars, policymakers and case workers can analyse Syrian refugee discourses.

Taken together, both HACKL's and KAMAL's contributions reinforce that, in trying to define refugeeness as an object of study, academicians have simplified the experience of displacement thereby creating what Liisa MALKKI calls the "generic refugee" (MALKKI 1992, p. 33; 1996, p. 389), a category removed from the empirical reality and serving policy objectives that rather than just explaining the phenomenon it tries to inscribe, becomes a "technology of power" governing the lives of refugees (MALKKI, 1985, p. 51; 1995). Furthermore, HACKL states that while scholarship on migration and refugees usually sees migrants as representing mobility and refugees as immobility, the interviews he analysed show that these two elements intersect, as entrapment leads to "forced mobility". While I am reticent to agree that refugees are usually perceived through immobility, since the focus today is on refugees in Europe and on how to restrain their supposed hyper-mobility, further development of the concept of "forced mobility" is promising. Such development would take "forced mobility" away from being simply a broad label to different sorts of legal and heuristic types of forced migration and apply the concept to the refugee experience of immobility instead, regardless of actual physical mobility. This is because the refugees' experience of flight and refuge - more so than their actual physical mobility - shapes their attitude toward the world at large, and 
countries of origin, social belonging, host states and integration policies in particular. While empirical and symbolic dimensions of violence and displacement are inherently intertwined, the dominance of mobility studies has often overemphasised the former over the latter ${ }^{2}$.

As HACKL suggests, long-term research is necessary to better understand the relationship between experiences of displacement and legal and political representations of displacement within international regimes and nation-state policies. By the same token, it is necessary to "bring refugee studiers home, into the context in which displacement emerges". Yet, I would add, the challenge ahead evokes not only more research or research elsewhere, but a complete qualitative change of perspective to include the refugee voices, plural as they are, within the realms of policy and research alike. In fact, according to FIDDIAN-QASMIYEH et al (2014, pp. 16-17), this is likely one of the most important tendencies leading to future ground-breaking research on refugees. Along with this perspective change, as countries in the global North increasingly refuse to receive refugees, it becomes evident that durable solutions for refugee crises are inherently political, rather than "just" humanitarian. It is first and foremost conflict and violence that must be resolved. Protracted refugee experience such as that experienced by the Iraqi, but also the Palestinian, the Syrian, and several other cases, are the most dramatic demonstration of this argument. In this sense, while the concept of integration circumscribes solutions to refugee crises within the realm of host nation-state policies, the encounter looks at the broad landscape seeking more profound connections and answers.

Overall, a context greatly affected by war and violence instils trauma, and refugees coming from such places need not only psychological care, but also time to adapt to a new environment that demands different values, behaviours, social norms, and even etiquette. In this sense, they cannot be expected to readily "integrate". Some integrate well, despite the difficulties they face, but this cannot be required or expected of all refugees. For this reason, while HACKL, like Tan, is right that the differentiation between migration and forced migration is in many cases arbitrary, it is important to note that it is the forced migration category that engulfs the other, and not the other way around. In other words, the maintenance of categories such as "forced migration" and "refugee", encompassing an understanding of trauma and precariousness and the procedures they require, is paramount. What runs the risk of losing some of its significance instead is the category "migrant" as it connotes only mobility and not displacement. Awareness of this fact is not obvious, since this assimilation does not follow the same patterns of the merging of the fields of refugee and migration studies, given that insights in both fields have been equally important to one another. This reality, however, does have consequences for understanding not only integration, but also tutelage. While the realisation that the legal category of "refugee" justifies some level of tutelage by host states, it also rules out integration as a precondition for refugee or asylum seeker

\footnotetext{
As emphasised in debates on globalization, but also as exemplified, for instance, by the journal Transfers: Interdisciplinary Journal of Mobility Studies or in Faist (2013).
} 
permanence in this state. Rather, if the nature of refugeeness (and not simply migration or mobility) is what is putting in motion a tutelary regime into motion, host countries need to be ready to offer the proper social tools to empower refugees to deal with their trauma and to integrate them within their new social context. By the same token, if integration is the desired result of refugee policies, then participative refugee policies should be not only a goal, but a means to achieve this end.

\section{On Humanity and Agency}

In her chapter in this volume, Sabine BAUER notes that agency is broadly understood as choice, and that the denial of choice is that which has been often characterising forced migration as opposed to other forms of migration. Consequently, she notes, scholarship on the topic has too often ignored individual decision-making while refugee aid institutions and case workers have too often ignored diversity at large. But do refugees in fact completely lack agency? If not, how do they reclaim agency that is being denied to them? How do they express their voices, stories, fears and dreams? Her chapter questions if all refugees fit the stereotypical imagery propagated by the media, as completely helpless and miserable. She assesses that while millions of refugees are indeed in such a situation, they do not always fit this stereotype, and among them, many of the refugees arriving in Austria in the summer of 2015.

According to BAUER, the humanitarian apparatus constructs these representations as "mechanisms of victimisation" depriving refugees of agency by creating "suffering objects" completely dependent on their action. However, regardless of their situation, many refugees resist this stereotype, and even though they are victims of persecution, violence and more, they prefer to be recognised as active agents of their own lives. This does not mean that they do not need help, but that they want to be treated as subjects, rather than merely as passive objects. They want to communicate their situation, be heard, and be part of the solution, rather than simply accept what is decided for them top-down. As BAUER states, a vital part of this solution is to reclaim their own agency and personhood, rather than being treated as generic refugees. Focusing on four interviews from the research's sample - all Syrians - she aims to present how they cope with such narratives of victimisation and reclaim agency. Her argumentation weaves well through the discussion on tutelage I have been presenting, for tutelage, both by the international refugee agency and by host nation states, has often hampered refugee agency and ultimately thus, integration, as I will present in what follows.

BAUER argues that by writing out class differences, those inscribing subjects within the "naked refugeeness" narrative seek to mobilise public support. Developing BAUER's thought, to class here we must add all other kinds of cleavages, be they ethnic, religious, national, etc. Despite these often good intentions, however, refugees themselves are often 
not heard. Other authors in this volume point to this same issue, which has been noted before by other anthropologists working on refugees or humanitarianism, as I will develop later in this introduction. To remain on topic now, what must be understood is that despite the good intentions, the asymmetry between refugees and their hosts and caretakers are still embedded in power relations not always fully acknowledged, as Michel FoucAulT (1980), Talal AsAD (1993), and Edward SAID (1985) masterfully contended at a more general level. According to BAUER, what the stereotypical image of refugees highlights above all is "unbearable hopelessness and poverty", which is conveyed especially through the image of women, children, and the elderly, as dispossessed of agency. Therefore, this representation acts as a mechanism of "gerontation", "genderisation", and most recently, also "racialisation" of refugees. BAUER does not state it overtly, but one could reflect that in the humanitarian imagination, men are often not suitable for this purpose because the common sense often associates them with the agency leading to the others' predicament. Or, in Mayanthi FernANDO's words, this imagery depends on the principle of "white men saving brown women" (2014) to succeed. The point here is that, as FoucAult, SAID, and especially AsAD would argue, this imagery caters equally to, for example, to Black Americans, but it belongs to a European "tradition" of thought (AsAD, 1986) presented as universal (FERNANDO, 2014). As BAUER suggests, according to this scheme, agency, and consequently power, are ascribed to the "rescuing" side, never to the "rescued". By the same token, the "problem of the refugees" is always perceived as emanating from the global South, and never contextualised within the post-colonial situation of the contemporary world, or of international geopolitics and especially Western intervention.

According to BAUER, this imagery of "naked refugeeness" - likely inspired by Giorgio Agamben $(1998,2005)$ - dehumanises refugees, turning them into "suffering objects". However, this is also part of the mechanism generating the rhetoric of the "generic refugee", as discussed by Liisa MALKKI $(1992,1995,1996)$. Thus, I offer an alternative perspective: this mechanism aptly described by BAUER creates a generic humanity as object of the humanitarian intervention, thereby effacing context (or as BAUER says, "temporality", entailing both history and the ability to shape the future) and personhood, and thus politics. Hence, it is mainly depolitisation (a mechanism also acknowledged by BAUER) that leads to the effacement of the refugees' personhood and agency. Ironically, by often being portrayed as the cause of displacement, men are frequently denied this status of generic refugees and generic humanity. Instead, they are frequently treated as over-politicization, as agents of a politics frequently at odds with their own perspective, and are thus this way also denied agency. Concomitantly however, BAUER is right that in assessing who is a refugee or not, and in denying the status to some based on the assessment of which countries are deemed "safe" or not, the humanitarian intervention also "nationalises" the refugees. It is thus more precisely the tension between generic humanity and nationality that drives the humanitarian intervention. In this sense, BAUER's concept of "the suffering object" underlined above is still very useful, only I suggest that it is depolitisation, inherent to the generic humanity, that 
which leads to the refugees becoming "suffering objects". Dehumanisation instead, via nationalisation and over-politicization, often prevents subjects from being considered refugees in first place.

Themes such as feelings, loss, and pain, traditionally left out of anthropology before the 1970s, have become fertile ground in anthropology today, and particularly in Middle East and Palestine anthropology. In this sense, engaging TRuillot's Anthropology and the Savage Slot (2003) Joel RoBbins' Beyond the Suffering Subject suggests a pivotal shift from an "anthropology of the savage" to one of the "suffering subject" (2013). More than being absorbed into the traditional psychological anthropology field, a whole new area, what has been called the "anthropology of suffering" (see FASSIN 2013, 2012; RobBins 2013; FeldMAN \& TickTin 2010; DAs 2007), is accommodating these topics. The current emphasis on political, religious, ethnic, and gender minorities reflects the contemporary world's ubiquitous political expression of civic contestation. Both TRUILLOT and RoBBins cite humanitarian thought and intervention as one of the main recent societal changes affecting anthropology, making a "humanity united in its shared vulnerability to suffering" its main focus of research (RoBbins, 2013, p. 450). Not surprisingly then, the suffering subject to RoBBINs is those who are "living in pain, in poverty, or under conditions of violence or oppression" (idem, p. 448). One must acknowledge that while anthropology has been thoroughly affected by the contemporary idea of humanity, it also deeply influenced the idea itself. However, where the humanitarian intervention takes it as face value, contemporary anthropology mostly seeks understand this generic humanity through its inherent diversity and contextual politics. BAUER's insightful chapter, as with others in this collection, serves as an example of how this effort may be fruitful beyond the realm of scholarship.

As we have established, the tension between ideals of humanity on one side, and the reality of peoples' social group (be it ethnic, religious, national, or of another kind) and personhood on the other is constitutive of discourses on refugees. Moreover, as Bauer reminds us, it is also constitutive of refugee experiences themselves. Refugees must navigate this contradiction in their daily lives, including when they address caseworkers, host states, journalists, and researchers. This can lead to what she calls "strategic essentialism", when refugees accept mainstream discourse on refugeeness developed above to express themselves and reclaim agency to further their own objectives, which more often than not includes access to aid. In other words, they often accept and express disempowerment as a means to empowerment. As the term "strategy" evokes conscious choice, I suggest developing Bauer's excellent insight even further. As any other subject, refugees navigate their predicament and their lives in general through not only conscious choice, pragmatic decision-making, and practical reason. As BAUER also reminds us, agency is closely linked to performance, agency as not only a consequence of subject's conscious choices, but also of subject's embodied dispositions, affects and sensibilities, all of which are enmeshed with subject's actions. Hence, I suggest that the term "contextual essentialism" may reflect a more comprehensive understanding of what drives motivating refugees' agency, as it does not evoke discerning practical 
reason from feelings, dispositions, and sensibilities, emanating from cultural, sociohistorical and political contexts.

Yet, BAUER also presents the case of a Syrian man, both refugee and activist, who felt disempowered in Austria, and "asked not to be treated like a child". Individuals such as him are far much more common than the humanitarian imagery would make believe, and cases like his expose flaws within the humanitarian imagination. reinforced by generic refugee imagery. Without context, will, or agency, the imagery of the generic refugee justifies a politics of tutelage.

\section{National-Humanitarian Order and Tutelage}

This edited volume offers intimate stories on the disrupted lives of Syrians, Iraqis, and Afghans both prior to deadly conflicts in the region and in exile. It also presents interpretations of sets of in-depth interviews, contributing to several topics in migration and forced migration studies. This qualitative examination is better understood in relation to the supportive quantitative analysis germane to this research. In this introductory chapter, I have proposed the concept of encounter as a more comprehensive academic frame for understanding the meeting between the refugees and Austria and the Austrians at large, reserving the term integration only to more policy-oriented interventions. Finally, I have also suggested that, taken together, the contributions in this volume address the imperative topic of the dynamics between encounter and tutelage, which is essential to uncover power relations shaping the social situation analysed and the consequent integration policies.

Another promising model scholars have recently mobilised that could flesh out power relations involved in the humanitarian intervention is Marcel Mauss' concept of "gift economy" (1990). However outstanding when applied to a variety of social situations, this model has few serious limitations when applied to the understanding of humanitarian intervention on refugees. The gift economy is characterised by three phases: giving, receiving and reciprocation. As opposed to the capitalist logic, giving is preferable to receiving, and accumulating is perceived as hoarding, leading to catastrophic social results. Since the act of giving must be reciprocated with a gift perceived as at least as valuable as the one received, during the time between giving and receiving reciprocation, the giver's moral status, and thus social standing, is elevated, generating or deepening hierarchy. This power relation cannot be simply avoided, since, much like a birthday present, the gift in this type of economy cannot be refused, for that would mean a refusal of the relationship expressed through the gift. In this economy, the same gifts circulate season after season, jumping from individual to individual. Each of these gifts is said to have a "spirit" (hau, in Kilivila). The longer a gift is in circulation, the higher status its spirit acquires. Thus, this type of "moral economy" presupposes a circuit that connects different parts of a society (or different societies) 
through reciprocity. The whole scheme can only happen because subjects alternate their roles in this system (MAuss, 1990).

Some applied this concept more directly to the humanitarian intervention (HAMID, 2012; JoLLIFFE 2016), and some more critically (FASSIN 2012), and few emphasise power relations. While power was not the main highlight of Mauss' famous essay, it was certainly accounted for in his model, and most of the scholarship emerging out of this essay, in one way or another, was interested in power relations (see, for example, LÉVIStrauss 1969; Dumont 1980; Strathern 1988; Lanna 2007; and the journal LA ReVUE DU MAUSS, standing for Mouvement anti-utilitariste dans les sciences sociales, or AntiUtilitarian Movement in the Social Sciences).

More importantly, I understand the gift economy described by Mauss as essentially different than the relationships established through humanitarian intervention particularly because reciprocity is severely limited or altered in humanitarian intervention (defined here as prompted either by the UN, international NGO's, or state actors - both hosts and donors). First, in the cases where the receiver of the gift directly reciprocates, reciprocation is not reciprocated in kind, given the social asymmetry between the parties; that is, while refugees may in rare but significant cases become donors, the humanitarian apparatus is not the same as refugees, and refugee aid is never intended to be reciprocated in kind. In fact, it is the acknowledged asymmetry between the parts that prompts the humanitarian apparatus to "give" in first place, the wellbeing of refugees in principle being that which brings symmetry (social justice) into the system. Second, reciprocation it is usually thought of as redirected to a third subject besides humanitarian intervention and the refugee who receives aid, following the moto "we help you so you can help others"). In both cases, as Barbara HARRELL-BOND correctly states (1986, 2002, 2005), the system creates eternal givers and eternal receivers, as opposed to fostering the generalised exchange and alternate social roles characteristic of the gift economy model. In sum, the principle of this system resembles that of charity, and charity and the gift economy are far from being the same. As FASsin richly states:

"It is not the condescension on the part of the persons giving aid or the intention of their act of assistance that are at stake, but the very conditions of the social relation between the two parties, which, whatever the goodwill of the agents, make compassion a moral sentiment with no possible reciprocity. It can of course be pointed out that the apparently disinterested gift assumes a counter gift in the form of an obligation linking the receiver to the benefactor - for example, the obligation on the receivers sometimes to tell their story, frequently to mend their ways, and always to show their gratitude. But it is clear that in these conditions the exchange remains profoundly unequal. And what is more, those at the receiving end of humanitarian attention know quite well that they are expected to show the humility of the beholden rather than express demands for rights." (FASSIN 2012, pp. 3, 4).

What is at stake here is both the principles of humanitarian intervention and the power relations they convey, what we understand as human, humanity and humane, and 
how we organise society around it. As I argued throughout this chapter, the relationship between the two can be in fact surprisingly contradictory. Tutelage, as opposed to the gift economy, lays bare relations of power constitutive of this social situation. Tutelage is what MalKKi $(1985$, p. 51, 1995) and Foucault (1980) combined would call a technology of biopower, meaning power over life, through which power is exerted asymmetrically across the system of forces at play. Tutelary regimes legitimise the dependency of protectorates, children, indigenous groups, national minorities, refugees, and other subjects perceived as not apt for deciding for themselves. In denying agency and full political participation and autonomy, tutelage objectifies ${ }^{3}$ and depoliticises, much like Agamben claims the state of exception does $(1998,2005)$.

As this volume shows, humanitarianism has its own vernacular politics, which is mobilised not only by the United Nations refugee agency, but also by NGOs, nationstates, the media, and the refugees themselves. Anthropologists working on refugees or on humanitarianism, such as Michel AgIER (2008, 2012), Ilana Feldman (2010), and Didier FASSIN (2012) have already pointed to the structure of the humanitarian discourse and apparatus. The principles and mechanisms of humanitarian aid depend on accepting nation state sovereignty above all. This, in turn, means that international treaties and "laws" relating to refugees, such as the Geneva Convention and its protocols, not only depend on each state's own agreement and interpretation, but also is contextually subject to nation-state rule in practice. That is, the application of such principles is left to each state's own devices. Institutions such as the United Nations (via UNHCR, UNRWA, and others) can only suggest resolutions on how to treat refugees, but not enforce them in practice. Accountability and enforcement mechanisms are usually limited to international sanctions, when these are actually put into practice. The decision always lies with the General Assembly, which is in itself composed of UN member states, voting according to their own interests. Humanitarian intervention is thus complementary to nation-state sovereignty, rather than opposite forces. As refugees by definition do not fit into any nation-state, they need to be governed by a force external to the nation-state order of the world that, in doing so, reinforces nation-state sovereignty. Tutelage, thus, embodies the power relations at play between refugees on one side and the national-humanitarian order of the world on the other.

At the base of this national sovereignty and international humanitarian intervention covenant lies the main principle behind humanitarianism: being apolitical. While this principle is most often naturalised as the beyond criticism, it has its limitations. Most importantly, most refugees perceive that the solution for their situation is not simply bed and board or to be taken (or not) to one or another country. The solution, for most, is

\footnotetext{
It must be noted that subjects are occasionally presented by the humanitarian intervention as both victims and active agents, like the human rights advocate and Nobel Prize laureate Malala Yousafzai. Such individuals only exist insofar as their own interests are completely aligned with those of their sponsors or when these interests are made look like as if they were. Yet, such individuals are presented as wonders, or as the exception that justify the humanitarian tutelary regime rather than international and national participative policies.
} 
inherently political. As victims of forced migration, refugees were obliged to leave their countries of origin or else suffer persecution and violence. On the one hand, by treating refugees as mere objects of humanitarian policy, they are understood in principle as apolitical. On the other hand, however, refugees are treated by host nation states as a political problem, rather than as humans just like any other citizen. In the nationalhumanitarian order of the world, thus, refugees are apolitical when they want to be political, and as political when they want to be taken as equal to other humans. This tension tends to frame the experience of refugeeness greatly, and has yet to be widely acknowledged by policymakers, humanitarian agents, and scholars alike.

As Bruno Latour (1993) states, to be modern was a project that entailed, for example, the separation of church and state. This project, however, was never actually fully realised in practice and that does not seem any closer to fruition today than it was decades ago. By the same token, I suggest that humanitarianism is also a project, one entailing the creation of a humanity beyond politics that could never be fully turned into reality, as it is curbed by the whims of the nation-states. Such a project cannot exist but within the relative and contextual space given to it by particular nationstate sovereignties. The result is a general policy of tutelage that conceals political contextualisation and with it the aspirations and lives of the refugees themselves. Supposedly beyond politics, humanitarianism has been often been considered beyond criticism too, and thus needs to be taken in scholarly perspective and understood as an ideology instead, in Louis Dumont's (1986) sense - that is, not opposed to truth, but as one truth regime among others. Nonetheless, my remarks must not be read as effacing the notable improvement humanitarian intervention has ensured for the lives of refugees, but instead as a testimony to the fact that no matter how outstanding this assistance is, it is only palliative to enduring political solutions. To be more precise, what I have presented so far suggests that it is the tutelary character of humanitarian intervention, legitimised as apolitical, which must be rethought and substituted by a more comprehensive, context-aware, practice; a practice that would take refugees as subjects of their own destinies, and assume the inherently political character of refuge situations, refugee subjects, and humanitarian practice itself.

Regardless of one's support or disfavour for refugee policies, taking the logic of tutelage fully into consideration highlight the rules of political engagement as inspired by liberal-democratic principles or respect for human dignity and autonomy: states who militarily or politically intervene in other states' affairs must take responsibility for their actions and receive eventual refugees coming from the intervened states' territories. This, in turn, must entail an understanding of the possible traumas and difficulties stemming from forced migration. Such refugees then cannot simply be expected to integrate or be deported. States that are not willing to take this responsibility must refrain from international intervention and tutelage in first place. Alternatively, such states should consider refugees as subjects capable of deciding their own fate, and thus develop participative refugee policies, rather than treating refugees as objects of the state's 
political objectives. In principle, this is actually the only alternative that could possibly justify the liberal-democratic principle of respect for human dignity and policies that hold refugees accountable for their own actions.

\section{Bibliography}

Abu-Lughod L. (2008), Writing Women's Worlds: Bedouin Stories. Berkeley, Univ. of California Press.

Agamben G. (1998), Homo Sacer: Sovereign Power and Bare Life. Stanford, Stanford University Press.

Agamben G. (2005), State of Exception. Chicago, The University of Chicago Press.

Agrer M. (2008), On the Margins of the World: The Refugee Experience Today. Cambridge, Polity Press.

AgIER M. (2012), Managing the Undesirables: Refugee Camps and Humanitarian Government. Cambridge, Polity Press.

Alston Ph. \& MacDonald E. (eds.) (2008), Human Rights, Intervention, and the Use of Force. Oxford, Oxford University Press.

Anonymous (1986), Tutelage. In: Webster's Third New International Dictionary. Springfield/MA, Merriam-Webster Inc., Publishers, p. 2470.

AsAD T. (1993), Genealogies of Religion: Discipline and Reasons of Power in Christianity and Islam. Baltimore, The Johns Hopkins University Press.

Asad T. (1986), The Idea of an Anthropology of Islam. Occasional Paper Series, Center for Contemporary Arab Studies. Georgetown University, pp. 01-22.

BARTh F. (1969), Ethnic Groups and Boundaries. The Social Organization of Culture Difference. Bergen, Universitets Forlaget.

Berman N. (2011), Passion and Ambivalence: Colonialism, Nationalism, and International Law. The Hague, Brill.

Brettell C. \& Hollifield J.F. (eds.) (2015), Theorizing Migration in Anthropology. Cultural, Social, and Phenomenological Dimensions of Movement. In: Migration Theory: Talking Across Disciplines. New York, London, Routledge, pp. 147-197.

Call Ch. (2008), The Fallacy of the "Failed State". Third World Quarterly, 29 (8), pp. 14911507.

Снatтy D. (2010), Displacement and Dispossession in the Modern Middle East. New York, Cambridge University Press.

Chakrabarty D. (2000), Provincializing Europe: Postcolonial Thought and Historical Difference. Princeton, Princeton University Press.

Das V. (2007), Life and Words: Violence and the Descent into the Ordinary. Los Angeles, University of California Press.

Dyck N. (1991), What is the Indian "Problem": Tutelage and Resistance in Canadian Administration. St John's, Memorial University of Newfoundland. 
Dumont L.(1980), Homo Hierarchicus: The Caste System and Its Implications. Chicago, University of Chicago Press.

Dumont L. (1986), Essays on Individualism: Modern Ideology in Anthropological Perspective. Chicago, University of Chicago Press.

Düvell F. (2014), Transit Migration in the European Migration Spaces. Politics, Determinants and Dynamics. In: Düvell F., Molodikova I. \& Collyer M. (eds.), Transit Migration in Europe. Amsterdam, Amsterdam University Press, pp. 209-236.

FaIer L. \& Rofel L. (2014), Ethnographies of Encounter. Annual Review of Anthropology, 43, pp. 363-77.

FaIsT T. (2013), The Mobility Turn: a New Paradigm for the Social Sciences? Ethnic and Racial Studies, 36 (11), pp. 1637-1646.

FANON F. (1965), The Wretched of the Earth. London, McGibbon \& Kee.

FAnON Franz. (1986), Black Skin, White Masks. London, Pluto Press.

FAssin D. (2013), Why Ethnography Matters: On Anthropology and its Publics. Cultural Anthropology, 28 (4), pp. 621-646.

FAssin D. (2012), Humanitarian Reason: A Moral Order of the Present. Berkeley, University of California Press.

Feldman I. \& Ticktin M. (eds.) (2010), In the Name of Humanity: The Government of Threat and Care. London, Duke University Press.

Fernando M. (2014), The Republic Unsettled: Muslim French and the contradictions of Secularism. London, Duke University Press.

Fiddian-QAsmiyen E., et al. (2014), Introduction: Refugee and Forced Migration Studies in Transition. In: Fiddian-QASmiYen E., et al. (eds.), The Oxford Handbook of Refugee and Forced Migration Studies Oxford, Oxford University Press, pp. 1-22.

Foucault M. (1980), Power/Knowledge: Selected Interviews and Other Writings, 1972-1977. Toronto, The Harvester Press.

Gadamer H.-G. (2004), Truth and Method. London, Sheed \& Ward Ltd and the Continuum Publishing Group.

Goertz G. \& Diehl, P. (1992), Toward a Theory of International Norms: Some Conceptual and Measurement Issues. The Journal of Conflict Resolution, 36, (4) (Dec., 1992), pp. 634664.

Goffman E. (1963), Stigma: Notes on the Management of Spoiled Identity. New York, Simon \& Schuster, Inc.

Goffman E. (1967), Interaction Ritual: Essays in Face to Face Behavior. New York, Anchor Books.

Goodson L. (2001), Afghanistan's Endless War. State Failure, Regional Politics, and the Rise of the Taliban. Seattle and London, University of Washington Press.

GuHA R. (1997), Dominance Without Hegemony: History and Power in Colonial India. Cambridge, Harvard University Press.

Halbwachs M. (1992), On Collective Memory. (edited and translated by Lewis A. Coser). Chicago, University of Chicago Press.

Hamid S. (2012), (Des)Integrando Refugiados: Os Processos do Reassentamento de Palestinos no Brasil. Doctoral Dissertation. Graduate Program in Anthropology, Universidade de Brasília. Brazil. 
Harrell-Bond B. (2005), Rights in Exile: Janus-Faced Humanitarianism. Oxford, Berghahan.

Harrell-Bond B. (2002), Can Humanitarian Work with Refugees be Humane? Human Rights Quarterly, 24, pp. 51-85.

Harrell-Bond B. (1986), Imposing Aid: Emergency Assistance to Refugees. Oxford, Oxford University Press.

JabBar F. \& Dawod H. (2003), Tribes and Power: Nationalism and Ethnicity in the Middle East. London, Saqi Books.

Joluiffe P. (2016), Learning, Migration and Intergenerational Relations: The Karen and the Gift of Education. Palgrave, McMillan.

Kleinman A. \& Kleinman J. (1996), The Appeal of Experience; The Dismay of Images: Cultural Appropriations of Suffering in Our Times. Daedalus 125 (1), Social Suffering, pp. 1-23.

Lanna M. (2007), God-parenthood and sacrifice in Northeast Brasil. Vibrant, 4 (2), pp.121-152.

LACAN J. (1949), "Le stade du miroir comme formateur de la fonction du je, telle qu'elle nous est révélée, dans l'expérience psychanalytique". Communication faite au XVIe Congrès international de psychanalyse, à Zurich le 17-07-1949. Première version parue dans la Revue Française de Psychanalyse 1949, volume 13, n 4, pp 449-455.

LA REVUE DU MAUSS, n/a. <http://www.revuedumauss.com.fr/Pages/APROP.html>. Accessed on February 18, 2017.

Latour B. (1993), We Have Never Been Modern. Cambridge, Harvard University Press.

LÉvi-Strauss C. (1969), Elementary Structures of Kinship. Boston, Beacon Press.

LimA A.C. DE Souza (2008), Traditions of Knowledge in Colonial Management of Inequality: Reflections on an Indigenist Administration Perspective in Brazil. World Anthropologies Network (WAN)/Red de Antropologías del Mundo (RAM), Electronic journal, 3, pp. 7-29.

Lima A.C. de Souza (1995), Um Grande Cerco de Paz. Poder Tutelar, Indianidade e Formação do Estado no Brasil. Petrópolis, Vozes.

Lindholm Ch. (1995), The New Middle Eastern Ethnography. Journal of the Royal Anthropological Institute, 1 (4), (Dec., 1995), pp. 805-820.

MaKdisi U. (2000), The Culture of Sectarianism: Community, History, and Violence in NineteenCentury Ottoman Lebanon. Los Angeles: University of California Press.

MaLkKi L. (1985), The Origin of a Device of Power: The refugee Camp in Post-war Europe. Special Paper submitted to the Department of Anthropology, Harvard University, Cambridge.

MalkKi L. (1992), National Geographic: The Rooting of Peoples and the Territorialization of National Identity among Scholars and Refugees. Cultural Anthropology, 7 (1), pp. 24-44.

MalkKi L. (1995), Purity and Exile: Violence, Memory, and National Cosmology among Hutu Refugees in Tanzania. Chicago, University of Chicago Press.

MaLkKi L. (1996), Speechless Emissaries: Refugees, Humanitarianism, and Dehistoricization. Cultural Anthropology, 11 (3), pp. 377-404.

Mamdani M. (1996), Citizen and Subject: Contemporary Africa and the Legacy of Late Colonialism. London, James Currey.

Mauss M. (1990), The Gift: The Form and Reason for Exchange in Archaic Societies. Oxford, Routledge.

Mrembe A. (2001), On the Postcolony. Berkeley, University of California Press.

Mignolo W. (2000), Local Histories/Global Designs. Princeton, Princeton University Press. 
Mokre M. (09/05/2016), How Do Lives Become Grievable? On the short summer of migration and the time after. ROR-n. <http://www.ror-n.org/-blog/how-do-lives-become-grievableon-the-short-summer-of-migration-and-the-time-after>

NAY O. (2013), Fragile and failed states: Critical Perspectives on Conceptual Hybrids. International Political Science Review, 34 (3), pp. 326-341.

OliverRa R.C. DE (1964), O Índio no Mundo dos Brancos: a Situação dos Tukúna do Alto Solimões. São Paulo, Difusão Européia do Livro.

Quijano A. (2007), Coloniality and Modernity/Rationality. Cultural Studies, 21 (2-3), pp. 168178.

PaInE R. (ed.) (1980), Ethnology: The White Arctic: Anthropological Essays on Tutelage Ethnicity. Toronto, University of Toronto Press.

Palmié S. \& Stewart Ch. (2016), For an Anthropology of History. HAU, Journal of Ethnographic Theory, 6 (1), pp. 207-36.

PAsserini L. (2014), Memory and Utopia: The Primacy of Inter-Subjectivity. Critical Histories of Subjectivity and Culture. Oxford, Routledge.

Radstone S. (ed.) (2000), Memory and Methodology. London, Bloomsbury.

Robins J. (2013), Beyond the Suffering Subject: Toward an anthropology of the Good. In: Journal of the Royal Anthropological Institute (JRAI), 19, pp. 447-462.

SA'di A. \& Abu-Lughod L. (2007), Nakba: Palestine, 1948, And the Claims Of Memory. New York, Columbia University Press.

SAID E. (1985), Orientalism: Western Representations of the Orient. Harmondsworth, Penguin Books.

Salazar N. \& Smart A. (eds.), (2011), Anthropological Takes on (Im)Mobility. Identities: Global Studies in Culture and Power, 18 (6), pp. i-ix.

SAYIGH R. (1998), Gender, Sexuality, and Class in National Narrations: Palestinian Camp Women Tell Their Lives. Frontiers, A Journal of Women Studies, 19 (2), Varieties of Women's Oral History (1998), pp. 166-185.

Schiocchet L (2017a.) The Middle East and its Refugees. In: Binder S. \& Fartacek G. (eds.) Facetten von Flucht aus dem Nahen und Mittleren Osten, pp. 101-122. Vienna, Austrian Academy of Sciences Press.

Schiocchet L. (2017b), The Austro-Palestinian Encounter. Arab Crossroads Program, NYU. Abu Dhabi. February 07, 2017. Lecture.

Schiocchet L. (2016), On the Brink of a State of Exception? Austria, Europe, and the Refugee Crisis. Critique and Humanism, 46 (2), pp. 211-248.

Schiocchet L. (2014a), Palestinian Refugees in Lebanon: Is the Camp a Space of Exception? Mashriq \& Mahjar, 2 (1), summer 2014.

Schiocchet L. (2014b), Suspicion and the Economy of Trust among Palestinian Refugees in Lebanon. Cambridge Anthropology, 32 (2), Autumn 2014, pp. 112-127.

SpIvak G.Ch. (1999), A Critique of Postcolonial Reason: Toward a History of the Vanishing Present. Cambridge, Harvard University Press.

Stocking JR. G.W. (1968), On the Limits Of "Presentism" and "Historicism" in the Historiography of the Behavioral Sciences. In: Race, Culture, And Evolution: Essays in the History of Anthropology. Chicago, University of Chicago Press, pp. 1-12. 
Strathern M. (1988), The Gender of the Gift: Problems with Women and Problems with Society in Melanesia. Los Angeles, University of California Press.

TAYlor Ch. (1992), Politics of Recognition. In: Gutmann A. (ed.) Multiculturalism and the "Politics of Recognition". Princeton, NJ, Princeton University Press, pp. 25-73.

Tedlock B. (2009), Performativity, Cultural Memory and Reverse Anthropology. Etnofoor 21 (2), Fear, pp. 105-114.

Trouillot M.-R. (2003), Anthropology and the Savage Slot: The Poetics and Politics of Otherness. In: Global Transformations, pp. 7-28. London, Palgrave McMillan.

United Nations (ed.) (1948). Universal Declaration of Human Rights. <http://www.un.org/en/ udhrbook/pdf/udhr_booklet_en_web.pdf> Accessed on February 23, 2017.

Wallerstein I. (2004), World-Systems Analysis: An Introduction. Durham, Duke University Press.

Wissink M. Düvell F. \& van EerdewiJK A. (2013), Dynamic Migration Intentions and the Impact of Socio-Institutional Environments: A Transit Migration Hub in Turkey. Journal of Ethnic and Migration Studies. <http://www.tandfonline.com/doi/full/10.1080/1369183X.2013.77 8026>. Accessed on February 14, 2017. 
